\title{
BULLA VIRGINEA.
}

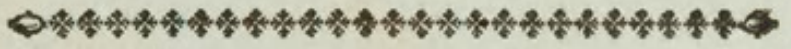

\section{CHARACTER GENERICUS.}

Animal limax.

Tefta univalvis, convoluta, inermis.

Apertura fubcoarctata, oblonga, longitudinalis. Columella obliqua, lævis.

$$
\text { Lin: Syft. Nat. p. } 1181 .
$$

ChaRACTER SPECIFICUS, Eृc.

BULLA ALBA, fafciis verficoloribus duplicatis, columella truncata purpurea.

BULLA TESTA fubturrita erecta, columella truncata fanguinea.

$$
\text { Lin. Syft. Nat. p. } 1186 .
$$

\section{BUCCINUM VIRGINEUM.}

$$
\text { Lin. Mus. Lud. Ulr. n. } 267 \text {. }
$$

In Afiæ fluviis præcipue reperta fedem fibi vindicat hæc concha inter pulcherrimas fui generis. Colore interdum variat; notas tamen femper retinet certas adeo et conftantes, ut de fpecie non poffit dubitari. 
THE

\section{RIBBAND BULLA.}

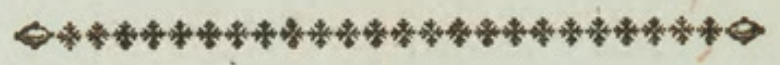

GENERIC CHARACTER.

Animal refembling a Limax or Slug.

Shell univalve, convoluted.

Aperture fomewhat ftraitened, oblong, longitudinal, entire at the bafe.

Column oblique and fmooth.

SPECIFIC CHARACTER, E̊c.

WHITE BULLA, with particoloured double bands, and purple truncated column.

The STRIPED BULLA.

The PAINTED BULLA.

This beautiful thell, which is juftly confidered as one of the mort elegant of the genus, is principally found in the rivers of Afia. It varies fometimes in its colors, but always retains characters fufficiently clear to determine the fpecies. 

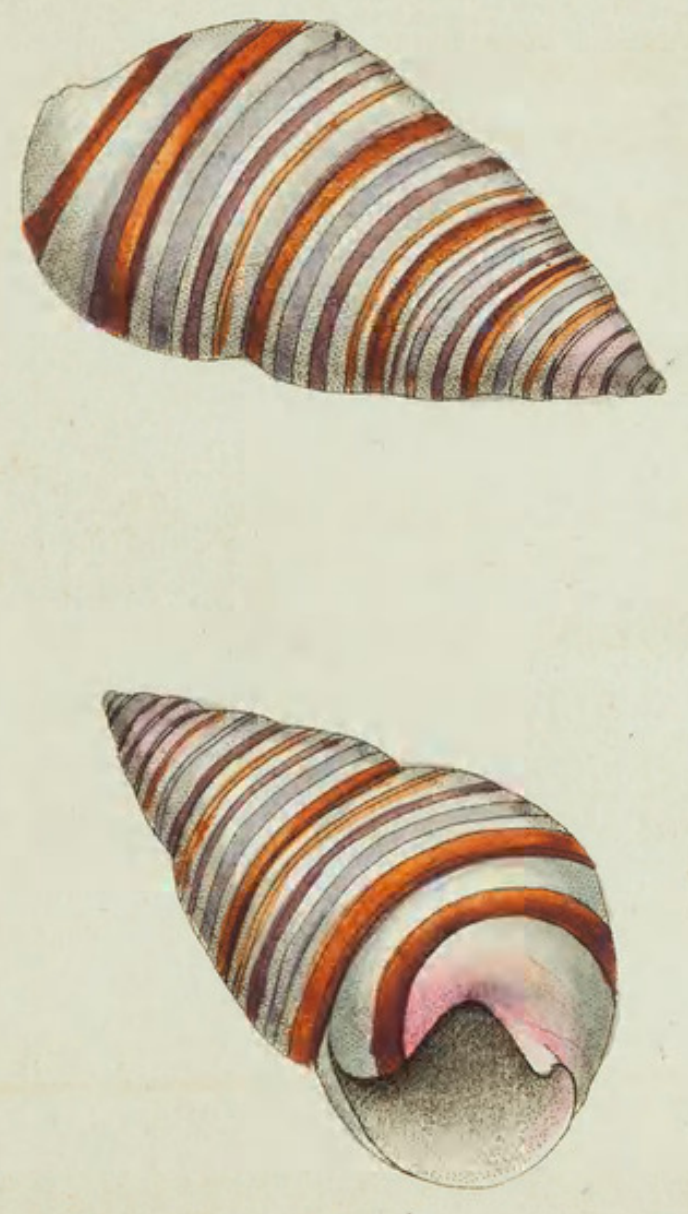

a. 


\section{$2 \mathrm{BHL}$ Biodiversity Heritage Library}

Shaw, George. 1797. "The Ribband Bulla, Bulla virginea [PI. 268]." The Naturalist's Miscellany 8(LXXXIX), https://doi.org/10.5962/p.310811.

View This Item Online: https://www.biodiversitylibrary.org/item/276320

DOI: https://doi.org/10.5962/p.310811

Permalink: https://www.biodiversitylibrary.org/partpdf/310811

\section{Holding Institution}

Museums Victoria

\section{Sponsored by}

Atlas of Living Australia

\section{Copyright \& Reuse}

Copyright Status: Public domain. The BHL considers that this work is no longer under copyright protection.

This document was created from content at the Biodiversity Heritage Library, the world's largest open access digital library for biodiversity literature and archives. Visit BHL at https://www.biodiversitylibrary.org. 